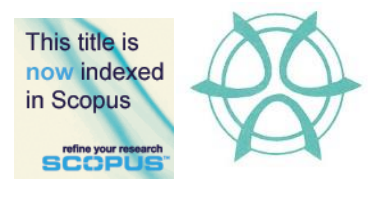

PLANNING MALAYSIA:

Journal of the Malaysian Institute of Planners

VOLUME XIV (2016), Page 55 - 66

\title{
A STUDY ON THE EFFECTS OF ROAD HUMPS IN REDUCING SPEED ALONG LOCAL ROADS IN RESIDENTIAL AREAS: CASE STUDY OF TAMAN SETIAWANGSA
}

\author{
Siti Syazwani Ahmad Sofi ${ }^{1}$ \& Abdul Azeez Kadar Hamsa ${ }^{2}$ \\ ${ }^{1,2}$ Kulliyyah of Architecture and Environmental Design \\ INTERNATIONAL ISLAMIC UNIVERSITY MALAYSIA
}

\begin{abstract}
The increasing number of vehicles along local roads in many residential areas has created unconducive environment and safety risk due to the increase in the speed passing vehicles. To control the speed of the vehicles, road humps were installed along local roads. This paper evaluates the effects of road humps on the speed of vehicles in Taman Setiawangsa, which is one of the residential areas in Kuala Lumpur. The field observational survey was carried out to collect data on design characteristics of the road humps. A spot speed survey was administered to collect spot speed of vehicles at different points near the road humps and the spot speed data at and near road humps were analysed using measures such as descriptive statistics and dependent t-Test. The design characteristics of the road humps were also compared with the existing road hump guidelines published by the authorities. The major finding of this study depicts the effectiveness of road humps in reducing speed in relation to the road hump's profiles.
\end{abstract}

Keywords: traffic calming measures, speed, road hump, residential area 
Siti Syazwani Ahmad Sofi \& Abdul Azeez Kadar Hamsa

A Study on the Effects of Road Humps in Reducing Speed Along Local Roads in Residential Areas

\section{INTRODUCTION}

According to Hamsa (2013), frequent changes in traffic component characteristics such as speed, capacity, road design and safety are considered as the implication of the increasing number of vehicles in a city or town. Reducing speed of vehicles in residential areas is not only necessary to protect pedestrian and bicyclists, but also other road users.

In global status report on road safety by World Health Organization, there are only 59 out of 114 countries which implemented the urban speed limit of 50 kilometre per hour $(\mathrm{kmh})$ or less. Various residential areas have deteriorated in the living environment aspect due to the issues such as increasing of traffic volume, excessive speed, road alignment and other related factors (Hamsa, Miura, Inokuma \& Nishimura, 2006). Consequently, the lifestyle of the residents is likely to get affected due to these factors, for instance; the sense of belonging and social interaction among the residents is in the risk to become worse as time goes by, particularly if there are no further alternatives to control the speeding vehicles.

In general, speed humps are well thought out as a viable and attractive measure in controlling speed of the vehicles since the drivers are forced to slow down their vehicles towards the speed hump. As mentioned by Roess, Prassas \& Mcshane (2004), the purpose of setting up speed humps is to reduce vehicle speed to tolerable level at certain pre-determined location along the residential road. Additionally, road accidents can be reduced, simultaneously improving the residents' well-being.

This paper aims to analyse the effects of road humps in reducing vehicle speed along the residential road in Taman Setiawangsa, Kuala Lumpur.

\section{LITERATURE REVIEW}

According to the Traffic Calming Guidelines in Malaysia, traffic calming has been defined as a method in which enables behavioural changes of drivers, pedestrians and other road users, who often interact on roads and sidewalks in the communities (HPU, 2002).

In order to create a safe living environment for the residents, the speed of the vehicles is reduced by installing speed humps along residential roads. This is supported by the Auckland Transport whom agreed that speed humps may improve the safety and amenity in a residential area (2013). In terms of safety, Appleyard (1981) recommended that when traffic volume increases beyond what is considered normal by the local residents, or when the vehicles speed increases because of street design, social street activities are greatly reduced, and the feeling of well-being in the affected neighbourhood is threatened. 
PLANNING MALAYSIA

Journal of the Malaysian Institute of Planners (2016)

\section{Road Hump and Speed}

Road hump or speed hump is one of the traffic calming measures installed mainly to control the speed of vehicles within permissible speed limit. To achieve lower speed, speed humps are installed at the desired locations mainly along residential roads. Road humps are able to create vehicle rocking motion that causes driver discomfort, thus results in most vehicles slowing down to about 20 mile per hour (mph) at the hump (ITE, 1999).

A study showed that vehicles tend to accelerate and achieve its initial approach speed at a certain distance after the hump compared to the speed at the hump (Karim, Ibrahim \& Arif, 2003). As road humps are placed mainly along residential roads having not more than two lanes and speed limit of $30 \mathrm{mph}$, it is considered safe for the residents to use the roads equipped with road humps.

Speed humps are normally three to four inches high and 12 to 22 feet long. The interval between road humps is 200 to 600 feet. The most common speed hump is usually 12 feet in length and 3 to 4 inches high with rounded, flat or parabolic shaped top (Johnson \& Nedzesky, 2004).

In Malaysia, there are limited studies and guidelines on the relationship between hump geometric designs, speeds and vibration (Manan \& Hoong, 2009; Zainuddin, Adnan, Rahman \& Diah, 2010). As a result, the implementation and outcomes of the traffic calming measures vary from one location to another (Marizwan et al, 2009).

Varhelyi (2002) discusses appropriate highest speed in different conditions (on wet or slippery road, at sharp curves, in darkness, and in decreased visibility), and a system that limits the maximal speed of the vehicle in the actual situation via in-vehicle equipment is proposed. It is estimated that the proposed system would result in $20 \%$ to $40 \%$ reduction of injury accidents in Sweden. Observing vehicle speed is one way to measure travel safety on the road. Essentially, high speed carries high risk, whereas low speed is considered as relatively safe.

In general, the impacts of traffic calming measures particularly road humps with regard to speed and safety varies greatly with type, geometry, location, spacing and other factors. A study conducted by Ewing (1999) in residential areas in North America shows the average percentage change of $85 \%$ speed after the installation of road hump is approximately $23 \%$. Another study in 2004 discovers that the average speed is reduced from 36.4 to $24.4 \mathrm{kmh}$, which is about $33 \%$ of reduction after the introduction of road humps in residential areas.

Sumner and Baguley (1979) state that the installation of road humps in certain residential areas in Britain appeared to be effective in that there has been a consistent reduction in vehicle speed. It has been found that no driver was observed to exceed $35 \mathrm{mph}$ with the humps in place. Traffic speed has been reduced to a level more tolerable to the residents and drivers who used the road. 
Siti Syazwani Ahmad Sofi \& Abdul Azeez Kadar Hamsa

A Study on the Effects of Road Humps in Reducing Speed Along Local Roads in Residential Areas

\section{RESEARCH APPROACH}

This section outlines the research objectives, methodology and limitations of this study.

\section{Research Objectives}

The objectives of this study include:

i. To estimate the vehicle speed distribution at selected points near road humps along residential road.

ii. To analyse the relationship between the characteristics of road humps and the speed of vehicles at and near the road humps.

iii. To recommend measures in reducing speed of vehicles in residential areas for a safe living environment.

\section{BACKGROUND OF STUDY AREA}

Taman Setiawangsa is a residential area which consists of low and high density housing, and a few commercial centres and public amenities. It is located in Setiawangsa, an area on the eastern suburb of Kuala Lumpur. It is surrounded by other residential neighbourhoods such as Wangsa Maju, Ampang Hilir and Keramat (Figure 1).

The housing areas in Taman Setiawangsa are provided with facilities such as mosque, schools, college and a hypermarket, which attract people and resulting in the increase of traffic volume in the area. Access to the area is via Jalan Taman Setiawangsa, which is connected to Jalan Jelatek. The Duta - Ulu Kelang Expressway (DUKE) has also made the area well connected by road network. Jalan Persiaran Setiawangsa, a residential road, was selected for this study. Besides, this road carries high traffic volume. 


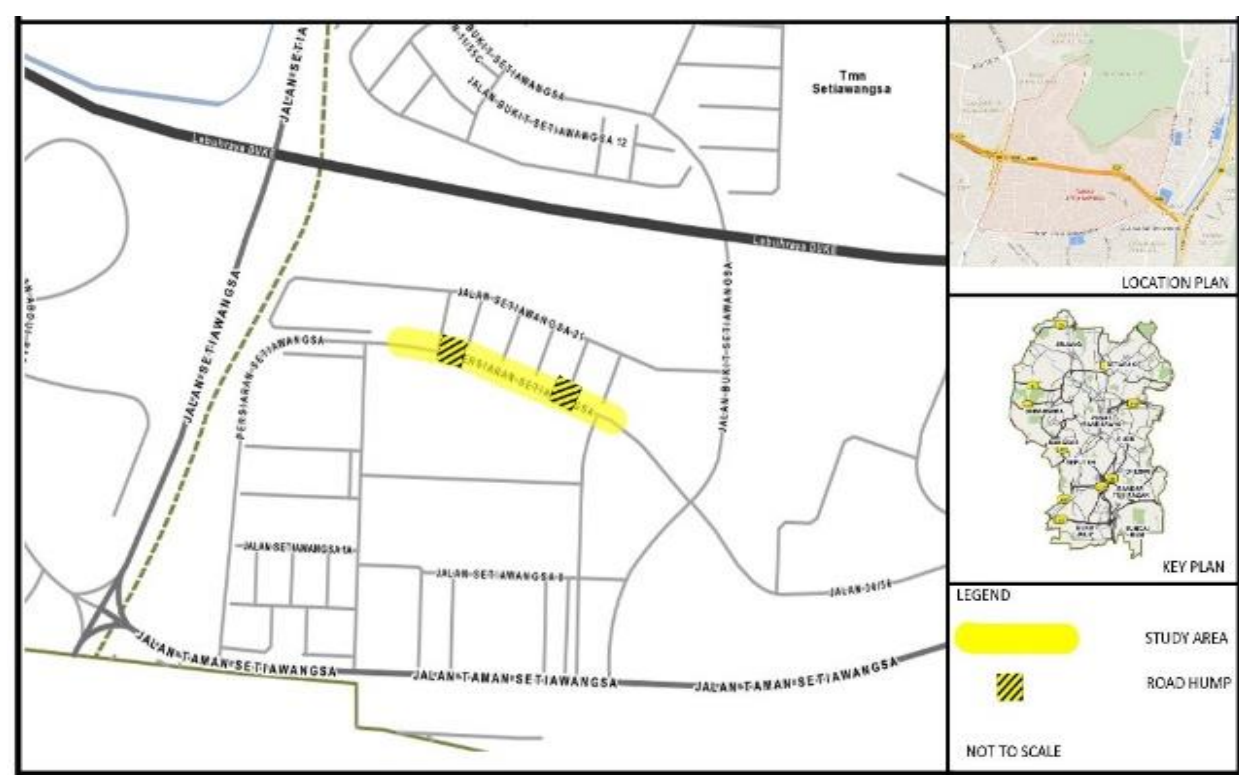

Figure 1 Location of Study Area

Source: http://kulsubmission.dbkl.gov.my/dbkl/kul_gis.html

In 2012, there was a landslide incident in Bukit Setiawangsa, near to Taman Setiawangsa. The main road to Bukit Setiawangsa where the landslide took place was closed due to reconstruction work. As a consequence, traffic volume at Persiaran Setiawangsa is slightly increased due to the change of traffic flow.

\section{INVENTORY SURVEY ON THE DESIGN CHARACTERISTICS OF ROAD HUMPS}

According to Bonsall \& O'Flaherty (as cited by Nur Shuhadah, 2014), inventory surveys, which are also referred to as condition surveys, are usually done to assist the identification of the suitable site for data collection, and at the same time to produce and update maps that will be used by researchers for data collection (1997). Therefore, certain secondary data in the study area were extracted before conducting the inventory survey. In this research, the inventory survey was administered to collect data on the design characteristics of road humps.

The design characteristics of road humps are used to identify the selection of road humps for determining the location for the spot speed survey. However, dimension of road hump (width, height and length) and spacing between the road humps were focused in this research.

\section{Spot Speed Survey}

A systematic sampling technique was applied for the selection of vehicles to measure spot speed. Every $2^{\text {nd }}$ car was targeted near the road humps to measure 
Siti Syazwani Ahmad Sofi \& Abdul Azeez Kadar Hamsa

A Study on the Effects of Road Humps in Reducing Speed Along Local Roads in Residential Areas

the spot speed of the car. A total sample size of 150 cars was selected for the measurement of spot speed.

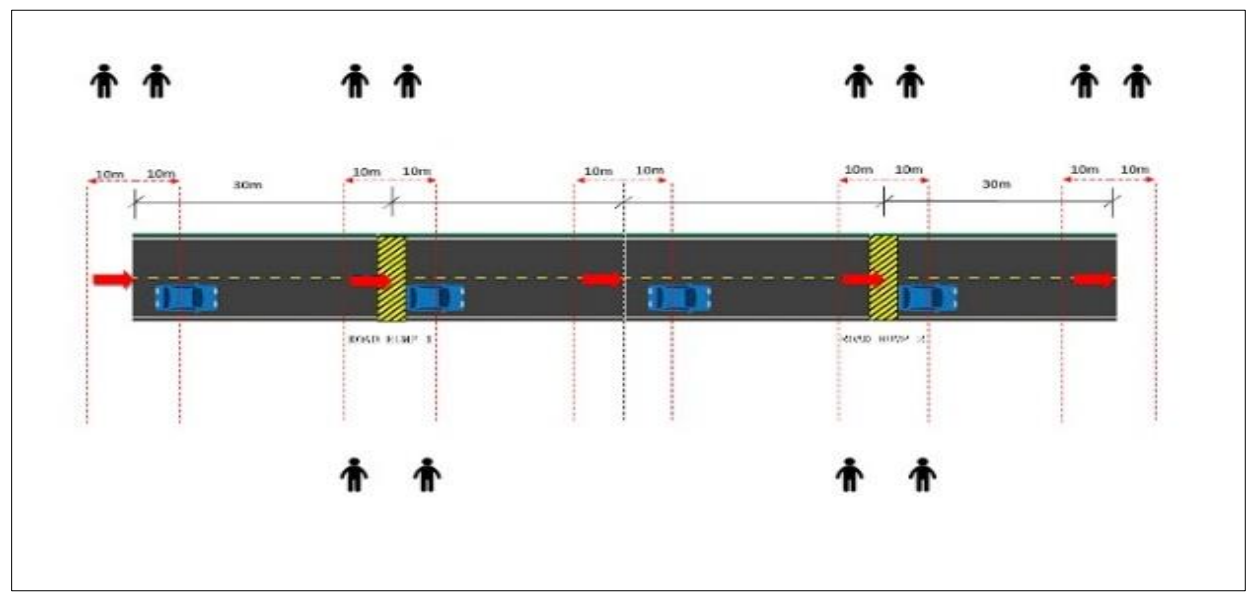

Figure 2 Spot Speed Location

Source: Site Survey, 2015

In this research, the spot speed of car was measured by applying directtiming procedures. Two road humps, Road Hump 1 and Road Hump 2 were selected along the residential road for the measurement of spot speed.

A total of five different points near the two road humps was chosen; the first point at a distance of 30 metres before Road Hump 1, the second at the Road Hump 1, the third between Road Hump 1 and Road Hump 2, fourth at Road Hump 2 and finally fifth point at the distance of $30 \mathrm{~m}$ after Road Hump 2 (Figure 2).

\section{Method of Analysis}

The data were analysed using descriptive analyses and dependent t-Test. Descriptive analysis comprises measures of central tendency such as mean speed, median speed, measures of relative position such as $85^{\text {th }}$ percentile speed and measures of variability such as standard deviation of the measured speed. Meanwhile, a dependent t-test was also applied to test the statistical difference in speed at different points of the two selected road humps.

\section{ANALYSIS AND FINDINGS}

\section{Road Hump Design Characteristics}

Based on the observation and analysis, both Road Hump 1 and 2 were circular in shape with 3.6 meters in length and 70 millimetres in height. The Guidelines by the Ministry of Works (2002) has indicated that the maximum height of a road 
hump should be 75 millimetres whereas minimum and maximum length is $3.7 \mathrm{~m}$ and $4.25 \mathrm{~m}$ respectively. The design characteristics of the selected road humps were provided by following the related guidelines on road humps.

Table 1 shows the comparison of design characteristics between the studied Road Humps and the guidelines provided by the Ministry of Works. The distance between the road humps is 34 meters which is far below the recommended distance of $60 \mathrm{~m}$ to $180 \mathrm{~m}$ as suggested by the guidelines.

Table 1 Comparison of Design Characteristics of Road Humps

\begin{tabular}{lll}
\hline Design Characteristics & Road Hump 1 \& & $\begin{array}{l}\text { Ministry of } \\
\text { Specification }\end{array}$
\end{tabular}

Source: Site Survey, 2015

A study on the relationship between speed humps, speed, volume and crashes by Portland Bureau of Transportation in 1998 has indicated how much distance is available for vehicles to accelerate and decelerate between humps based on its clear spacing. Generally, shorter spacing between humps results in lower speeds as the vehicles generally have less time to accelerate and decelerate between the humps.

\section{Spot Speed Analysis}

The lowest speed recorded at 30 meters before approaching the road hump was $30.86 \mathrm{kmh}$ and the speed dropped to $2.92 \mathrm{kmh}$ at the first road hump. However, the speed began to increase $(32.3 \mathrm{kmh})$ between the road humps and again decreased to $2.85 \mathrm{kmh}$ at the second road hump. Speed began to increase again to $44.44 \mathrm{kmh}$ after passing the second road hump (Figure 3).

On the other hand, the highest speed 30 meters before road hump was $93.1 \mathrm{kmh}$ and reduced to $10.2 \mathrm{kmh}$ at Road Hump 1. The speed increased to 75.09 $\mathrm{kmh}$ between the road humps and dropped to $9.6 \mathrm{kmh}$ at Road Hump 2. After passing Road Hump 2, the speed increased to $53.73 \mathrm{kmh}$ (Figure 3). 
Siti Syazwani Ahmad Sofi \& Abdul Azeez Kadar Hamsa

A Study on the Effects of Road Humps in Reducing Speed Along Local Roads in Residential Areas

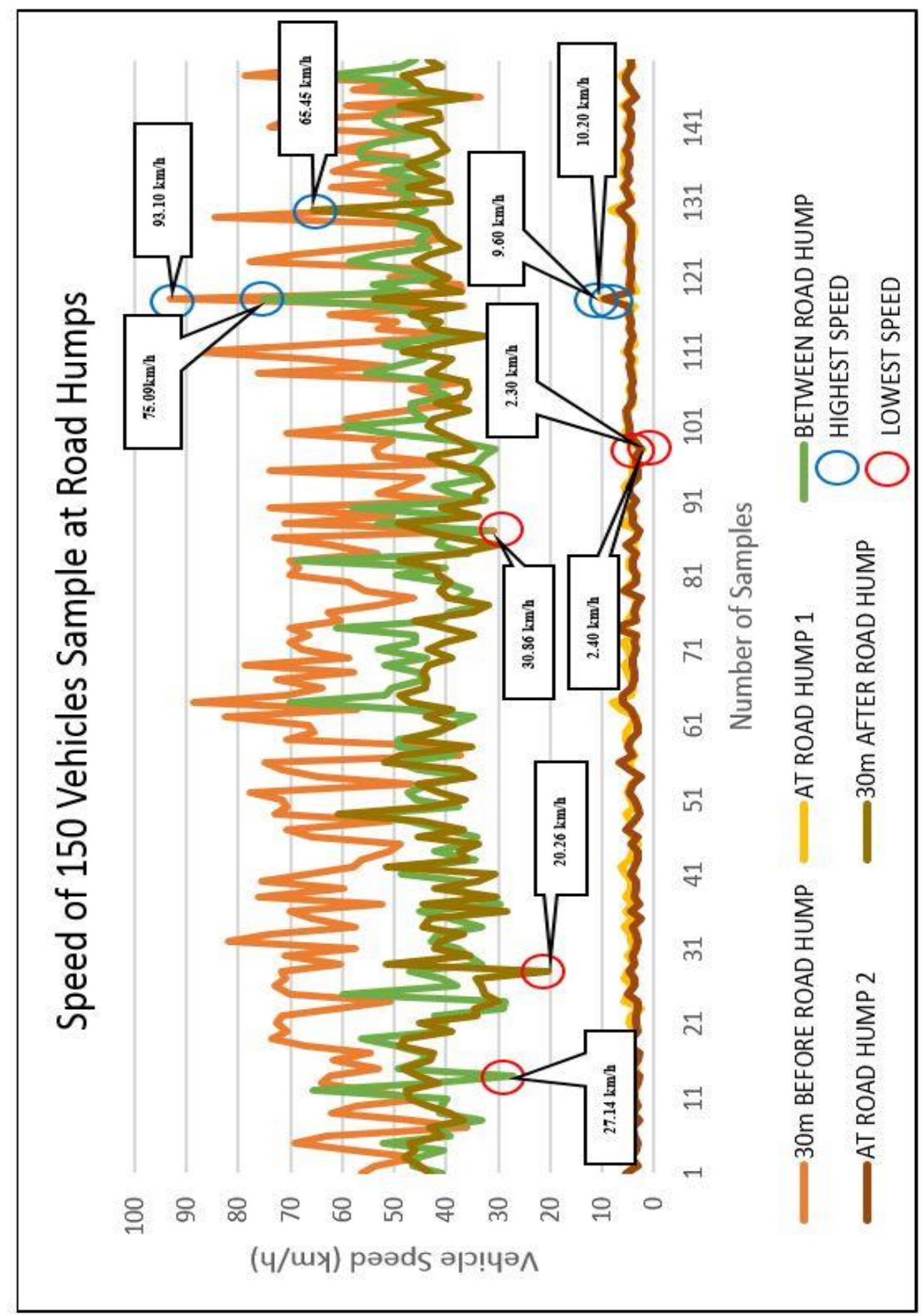

Figure 3 Speed of 150 Vehicles Samples Source: Site Survey, 2015 
Generally, acceleration took place between the road humps. The lowest speed recorded between the road humps was $27.24 \mathrm{kmh}$ and after leaving Road Hump 2 was $20.26 \mathrm{kmh}$. On the other hand, the highest speed recorded between the road humps was $75.09 \mathrm{kmh}$, and 30 meters after Road Hump 2 was 65.45 kmh.

The average speed of the cars at each point varies between one another. The average speed of cars 30 meters before Road Hump 1 was $59.93 \mathrm{kmh}$ while 30 meters after Road Hump 2 was $41.27 \mathrm{kmh}$. At Road Hump 1, the average speed was $4.63 \mathrm{kmh}$, while at Road Hump 2 was $4.2 \mathrm{kmh}$. Furthermore, the average speed of cars between the road humps was $42.5 \mathrm{kmh}$ (Table 2).

Table 1 Measures of Central Tendency

\begin{tabular}{llll}
\hline CENTRAL TENDENCY & MEAN SPEED & MODAL SPEED & $\begin{array}{l}\text { MEDIAN } \\
\text { SPEED }\end{array}$ \\
\hline 30m before Road Hump 1 & $59.93 \mathrm{~km} / \mathrm{h}$ & $72.5 \mathrm{~km} / \mathrm{h}$ & $60 \mathrm{~km} / \mathrm{h}$ \\
\hline At Road Hump 1 & $4.63 \mathrm{~km} / \mathrm{h}$ & $4.5 \mathrm{~km} / \mathrm{h}$ & $4.56 \mathrm{~km} / \mathrm{h}$ \\
\hline Between Road Hump 1 \& 2 & $42.5 \mathrm{~km} / \mathrm{h}$ & $42.5 \mathrm{~km} / \mathrm{h}$ & $44 \mathrm{~km} / \mathrm{h}$ \\
\hline At Road Hump 2 & $4.2 \mathrm{~km} / \mathrm{h}$ & $4.5 \mathrm{~km} / \mathrm{h}$ & $4.15 \mathrm{~km} / \mathrm{h}$ \\
\hline 30m after Road Hump 2 & $41.27 \mathrm{~km} / \mathrm{h}$ & $42.5 \mathrm{~km} / \mathrm{h}$ & $41.6 \mathrm{~km} / \mathrm{h}$ \\
\hline Source: Site Survey, 2015 & & &
\end{tabular}

Modal and median speed can be referred from Table 2. Most of the cars were moving above the posted speed limit which is $35 \mathrm{kmh}$. The highest speed between all points was $72.5 \mathrm{kmh}$, which was 30 meters before Road Hump 1. Yet, the speed at both humps reflected the efficiency of the humps. The modal speed at both humps measured at $4.5 \mathrm{kmh}$. Roughly, $37 \%$ of the cars drove at the speed of $42.5 \mathrm{kmh}$ after Road Hump 2.

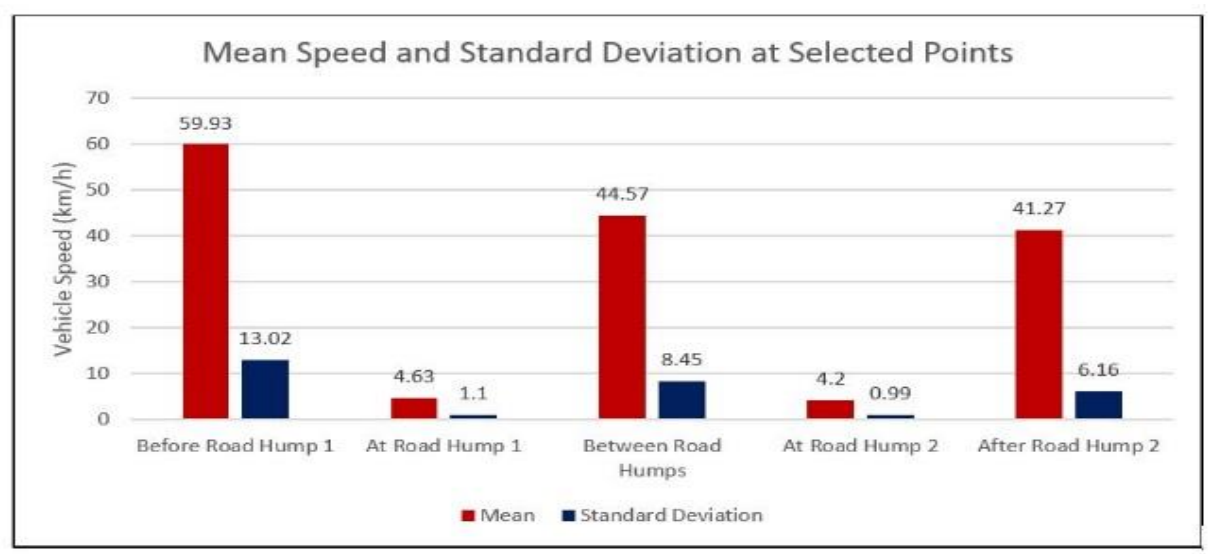

Figure 4 Mean Speed and Standard Deviations at Selected Points Source: Site Survey, 2015 
Siti Syazwani Ahmad Sofi \& Abdul Azeez Kadar Hamsa

A Study on the Effects of Road Humps in Reducing Speed Along Local Roads in Residential Areas

Mean speed of vehicles decreased while approaching the road humps and increased after leaving the humps. The speed reduced about $38.3 \mathrm{kmh}$ to 55.3 $\mathrm{kmh}$ before road humps compared to the speed after road humps which increased up to $37 \mathrm{kmh}$. The installation of the road humps has induced the vehicles to slow down effectively below the stipulated speed limit but it is not the case at other points either before, in between or after the road humps.

As illustrated in Figure 3, the variation in speed at all points were differed specifically at point before, between and after humps. The standard deviation of speed at both humps was low, but high at other points.

The $85^{\text {th }}$ percentile speed (Table 3 ) shows that 85 percent of the cars at Road Hump 1 were moving at the speed of $5.65 \mathrm{kmh}$ or below, and at Road Hump 2 at $5.86 \mathrm{kmh}$ or below. Consequently, the installation of the road humps has proved effective in curbing the speed of the vehicles and eventually helps to achieve the safe allowable speed limit of the residential areas.

Table 2 85th and 15th Percentile

\begin{tabular}{|c|c|c|c|c|c|}
\hline LOCATION & $\begin{array}{l}\text { 30m before } \\
\text { Road } \\
\text { Hump } 1\end{array}$ & $\begin{array}{l}\text { At Road } \\
\text { Hump } 1\end{array}$ & $\begin{array}{l}\text { Between } \\
\text { Road } \\
\text { Hump } 1 \text { \& } \\
2\end{array}$ & $\begin{array}{l}\text { At Road } \\
\text { Hump } 2\end{array}$ & $\begin{array}{l}\text { 30m after } \\
\text { Road } \\
\text { Hump } 2\end{array}$ \\
\hline $\begin{array}{l}8^{\text {th }} \\
\text { PERCENTILE }\end{array}$ & $73.58 \mathrm{~km} / \mathrm{h}$ & $5.65 \mathrm{~km} / \mathrm{h}$ & $52.76 \mathrm{~km} / \mathrm{h}$ & $5.86 \mathrm{~km} / \mathrm{h}$ & $46.31 \mathrm{~km} / \mathrm{h}$ \\
\hline $\begin{array}{l}15^{\text {th }} \\
\text { PERCENTILE }\end{array}$ & $44.75 \mathrm{~km} / \mathrm{h}$ & $3.05 \mathrm{~km} / \mathrm{h}$ & $35.94 \mathrm{~km} / \mathrm{h}$ & $3.22 \mathrm{~km} / \mathrm{h}$ & $34.46 \mathrm{~km} / \mathrm{h}$ \\
\hline
\end{tabular}

The difference in speed which before and at Road Hump 1 (Pair 1) and at Road Hump 1 and Road Hump 2 (Pair 2) were tested for statistical significance by using t-test. The results show that both tests were statistically significant at 95\% confidence interval (Table 4 and 6 ).

The findings show that there was a significant difference in the speed of vehicles for both pairs. In addition, there was also significant decrease in speed before road hump $(\mathrm{M}=59.93, \mathrm{SD}=13.02)$ to Road Hump $1(\mathrm{M}=4.63, \mathrm{SD}=$ $1.1), \mathrm{t}(298)=51.83, \mathrm{p}<.0001$. Pair 2 also shows significant decrease in speed from Road Hump $1(\mathrm{M}=4.63, \mathrm{SD}=1.1)$ to Road Hump $2(\mathrm{M}=4.2, \mathrm{SD}=0.99)$, $\mathrm{t}(298)=3.56, \mathrm{p}<.0004$ (Refer Table 5 and 7$)$.

Table 4 Paired Samples Statistics for Vehicle Speed

\begin{tabular}{cllll}
\hline & Mean & N & Std. Dev. & Std. Error Mean \\
\hline Pair 1 Before Road Hump 1 & 59.93 & 150 & 13.02 & 1.06 \\
\hline At Road Hump 1 & 4.63 & 150 & 1.1 & 0.09 \\
\hline
\end{tabular}

Source: Site Survey, 2015 
PLANNING MALAYSIA

Journal of the Malaysian Institute of Planners (2016)

Table 5 Paired Samples Test for Vehicle Speed

\begin{tabular}{|c|c|c|c|c|c|c|c|c|}
\hline & \multicolumn{5}{|c|}{ Paired Differences } & \multirow{3}{*}{$\mathbf{t}$} & \multirow{3}{*}{ df } & \multirow{3}{*}{$\begin{array}{l}\text { Sig. } \\
(2 \\
\text { tailed })\end{array}$} \\
\hline & \multirow[t]{2}{*}{ Mean } & \multirow{2}{*}{$\begin{array}{l}\text { Std. } \\
\text { Dev. }\end{array}$} & \multirow{2}{*}{$\begin{array}{l}\text { Std. } \\
\text { Error } \\
\text { Mean }\end{array}$} & \multicolumn{2}{|c|}{$\begin{array}{l}95 \% \text { confidence } \\
\text { interval of the } \\
\text { difference }\end{array}$} & & & \\
\hline & & & & Lower & Upper & & & \\
\hline $\begin{array}{l}\text { Pair 1 } \\
\text { Before - } \\
\text { At }\end{array}$ & 55.3 & 13.068 & 1.067 & 53.2005 & 57.3995 & 51.8341 & 298 & 0.0001 \\
\hline
\end{tabular}

Table 6 Paired Samples Statistics for Vehicle Speed

\begin{tabular}{rllll}
\hline & Mean & N & Std. Dev. & Std. Error Mean \\
\hline Pair 2 At Road Hump 1 & 4.63 & 150 & 1.1 & 0.09 \\
\hline At Road Hump 2 & 4.2 & 150 & 0.99 & 0.08 \\
\hline
\end{tabular}

Source: Site Survey, 2015

Table 7 Paired Samples Test for Vehicle Speed

\begin{tabular}{|c|c|c|c|c|c|c|c|c|}
\hline & \multicolumn{5}{|c|}{ Paired Differences } & \multirow{3}{*}{$\mathbf{t}$} & \multirow{3}{*}{ df } & \multirow{3}{*}{$\begin{array}{l}\text { Sig. } \\
(2 \\
\text { tailed })\end{array}$} \\
\hline & \multirow[t]{2}{*}{ Mean } & \multirow{2}{*}{$\begin{array}{l}\text { Std. } \\
\text { Dev. }\end{array}$} & \multirow{2}{*}{$\begin{array}{l}\text { Std. } \\
\text { Error } \\
\text { Mean }\end{array}$} & \multicolumn{2}{|c|}{$\begin{array}{l}\text { 95\% confidence } \\
\text { interval of the } \\
\text { difference }\end{array}$} & & & \\
\hline & & & & Lower & Upper & & & \\
\hline $\begin{array}{l}\text { Pair } 2 \\
\text { At - At }\end{array}$ & 0.43 & 1.482 & 0.121 & 0.1922 & 0.6678 & 3.5586 & 298 & 0.0004 \\
\hline
\end{tabular}

\section{CONCLUSION}

Overall, road humps are considered effective in reducing the speed of vehicles in residential areas. However, installing more road humps can also attribute to undesirable effects on the surrounding environment by increasing air and noise pollution due to sudden and frequent acceleration and deceleration of vehicles. Based on the findings, the speed of vehicles was greatly reduced at road humps.

The findings also show that the spacing between the selected road humps, which was 34 meters, is considered inadequate since the traffic calming guidelines suggested it should be at least 100 meters. Shorter spacing between road humps will contribute high air pollution and fuel consumption. Research in Austria shows that cars negotiating along a mile long stretch of road with six humps at $40 \mathrm{kmh}$ speed limit had emitted nitrogen oxides as high as 10 times, poisonous carbon monoxide as high as 3 times, and additional 25\% carbon dioxide when compared with vehicles maintaining a constant speed. The study also show that the fuel consumption of the vehicles has increased from 7.9 litres to nearly 10 litres per $100 \mathrm{~km}$. 
Siti Syazwani Ahmad Sofi \& Abdul Azeez Kadar Hamsa

A Study on the Effects of Road Humps in Reducing Speed Along Local Roads in Residential Areas

It is evident that road humps can help in controlling the speed of the vehicles, nevertheless at the same time it also creates unnecessary air and noise pollution which could be detrimental to the well-being of the society in the long run. To help alleviate the problem of speeding especially along residential roads, it is imperative to apply strict enforcement in order to control the driving behaviour of the motorists. On the other hand, the speed of vehicles can be reduced by avoiding a very long and straight road stretch especially in residential areas.

\section{REFERENCES}

Appleyard, D. (1981). Livable Streets. CA USA: University of California Berkeley.

Auckland Transport (2013). Traffic calming devices and local area traffic management. In Auckland Transport Code of Practice.

Institute of Transportation Engineers (ITE). (1999). Traffic Calming: State of the Practice. Retrieved from http://www.ite.org/traffic/tcstate.asp.

Hamsa, A. A. K. (2013). Urban Traffic System. Kuala Lumpur: IIUM Press.

Hamsa, A. A. K., Miura M., Inokuma S. \& Nishimura Y. (2006). Evaluating the Living Environment in Residential Areas at Taman Melati, Kuala Lumpur. Journal of Asian Architecture and Building Engineering, 5(2), 377-384.

Highway Planning Unit (HPU) (2002). Traffic Calming Guidelines. Kuala Lumpur: Ministry of Works.

Johnson, L. \& Nedzesky, A. J. (2004). A comparative study of speed humps, speed slots and speed cushions. ITE Annual Meeting and Exhibit, 14.

Karim. M. R., Ibrahim, N. I. \& Arif, W. R. (2003). Road humps as traffic calming devices. Eastern Asia Society for Transportation Studies.

Manan, M. M. A. \& Hoong, A.P. (2009). Traffic Calming Scheme in the Vicinity of Schools in Malaysia: A Survey in the Klang Valley, MIROS Evaluation Report (MER 11-2009). Retrieved from https://www.miros.gov.my/1/publications.php?id_page=19 \&id_event $=91$

Nur Shuhadah Mohd (2014). The Effect of Rumble Strips on Speed along MRR2. Final Year Thesis, Department of Urban and Regional Planning, IIUM.

Bonsall, P.W. \& O'Flaherty, C.A. (1997). Transport Planning and Traffic Engineering. Amsterdam: Elsevier.

Portland Bureau of Transportation (1998). Relationships between Speed Bumps, Speeds, Volumes, and Crashes.

Roess, R. P., Prassas, E. S. \& Mcshane, W. R. (2004). Traffic Engineering, 3rd Edition. New Jersey: Pearson Prentice Hall.

Sumner, R. \& C. Baguley (1979). Speed Control Humps on Residential Road (TRRL Laboratory Report 878). Crowthorne: Transport and Road Research Laboratory.

Varhelyi, A. (2002). Dynamic speed adaptation in adverse conditions. IATSS Research, 26(2), 5259. DOI: $10.1016 / \mathrm{S} 0386-1112(14) 60043-1$

World Health Organization (WHO) (2013). Global Status Report on Road Safety. World Health Organization.

Zainuddin, N. I., Adnan, M. A., Rahman, M. Y. A. \& Diah, J. M. (2010). Improvised engineering specification design for road hump: a case study in residential street Shah Alam. Proceeding of Malaysian Universities Transportation Research Forum and Conferences 2010. 